\title{
Willingness to Pay and Accept for Hosting Olympic Games in Germany
}

\author{
By Linn-Brit Bakkenbüll ${ }^{*} \&$ Alexander Dilger ${ }^{ \pm}$
}

\begin{abstract}
This empirical study investigates whether and how much individuals are willing to pay for hosting Olympic Games in Germany. Moreover, it is examined for the first time what individuals are willing to accept to host Olympic Games in their own country if they do not like that. Furthermore, this study identifies determinants that influence the willingness to pay (WTP) including the willingness to accept (WTA) for hosting Olympic Games in Germany. Extrapolations of the individual WTP and WTA show that, in the net aggregate, the German population is willing to pay $€ 3.57$ billion for hosting the Olympic Games in Germany.
\end{abstract}

Keywords: contingent valuation method, Olympic Games, willingness to accept, willingness to pay

\section{Introduction}

Hosting mega sport events like the Olympic Games primarily serves the goals to expedite regional development in one big push and/or to present the country to the rest of the world in a new light regarding openness, freedom and modernity. Typically, the achievement of these goals is associated with high costs but little success. An excellent example for this is the 2014 Winter Olympic Games in Sotschi. With approximately $\$ 55$ billion these were the most expensive Olympic Games ever in terms of cost per event. However, the benefit from the Olympic Games is limited. Extensive construction led to hotel overcapacities. Investors defaulted on state-backed loans. Additionally, there is no coherent plan for the after use of venues and some of the largest infrastructure projects. Moreover, the sport event did not improve the image of Russia in the world (Müller 2014). The example of Sotschi shows that hosting Olympic Games does not inevitably lead to positive effects. Consequently, cities or countries should consider carefully whether candidacy to host Olympic Games in the own city or country is advantageous. For example, Germany was interested in hosting the 2022 Winter Olympic Games in Munich and in hosting the 2024 Summer Olympic Games in Hamburg. Two local referenda, where immediately affected communities had the possibility to take part in the decision, vehemently spoke out against the plans.

This study examines the question how much German individuals are willing to pay or willing to accept to host the Olympic Games in their country. Considering willingness to accept in this context is new to the literature. Thus, our study is the first to simultaneously take into account both the willingness to pay (WTP) and the willingness to accept (WTA) to host the Olympic Games in Germany. Note that

\footnotetext{
*Ex Research Associate, University of Münster, Germany.

${ }^{ \pm}$Professor, University of Münster, Germany.
} 
the WTA has to be interpreted as a negative WTP, how much compensation Germans who are against hosting the Olympic Games in Germany need to accept hosting them there (see the chapters on methodology and data below). Furthermore, this article focuses on the identification of determinants that influence the WTP and WTA. For example, it is plausible to assume that individuals with a lager interest in the Olympic Games or in sport in general may have a higher (lower) WTP (WTA) than those who are less interested. Less interested individuals might rather reveal a negative WTP (to interpret as the WTA) to host the Olympic Games in their country. In a second step, we extrapolate the individual WTP to get the aggregated WTP of the German population.

The paper is organised as follows: The next chapter reviews existing literature referring to our object of investigation. The following two chapters present theoretical and methodological basics. The fifth chapter describes the data set. The next chapter shows the empirical results starting with the descriptive statistics followed by the regression analysis to identify important factors influencing the WTP, and an extrapolation of the individual WTP. The last chapter concludes the paper and outlines directions for further research and limitations of the paper.

\section{Literature Review}

This chapter provides an overview of existing literature with respect to hosting Olympic Games in the own country. To the best of our knowledge, there are six studies that measure the WTP for hosting the Summer Olympic Games. Two out of the six studies focus on the 2012 Summer Olympic Games in London. Atkinson et al. (2008) asked residents from London, Manchester and Glasgow about their individual WTP for hosting the Summer Olympic Games in London. The analysis shows that on average residents from London are willing to pay $£ 21.95\left(€ 24.46^{1}\right)$. Residents from Manchester (£12.40, €13.82) and Glasgow $(£ 10.87, € 12.11)$ are also willing to pay, yet less money on average. The results of this study show that residents from the city, in which the Olympic Games might take place, as well as residents from surrounding towns are willing to pay. Walton et al. (2008) confirm these results. They show that residents who are not living in London have a positive and not inconsiderable WTP for hosting the Summer Olympic Games in London. More precisely, residents from Bath are on average willing to pay $£ 70.11$ (€78.14). An extrapolation over the median of $£ 42.20$ (€47.03) shows that the residents of Bath are willing to pay $£ 5.83$ million (€6.50 million) for hosting this event in London.

Wicker et al. (2017) employed a payment card format, which contains monthly tax amounts to determine the individual WTP for Summer Olympic Games in Germany over a five-year period. The study shows that respondents are on average willing to pay $€ 51$. Thereby, the WTP varied widely across regions, ranging from $€ 31$ in Hanover to $€ 100$ in the Cologne area. An aggregation of the WTP leads to a value of $€ 46$ billion. Wicker and Coates (2018) asked weeks before the official

${ }^{1}$ British pound equals $€ 1.1145$ by now. Retrieved from: http://www.finanzen.net/waehrungsrechner/ britische-pfund_euro. [Accessed 13 June 2020.] 
referendum in Hamburg (and Kiel) in November 2015 about hosting the Summer Olympic Games 2024 there. In the referendum 51.6 percent voted against bidding for hosting the games. In the survey with 368 included and weighted respondents only 41.3 percent were in favour and 30.2 percent had a positive WTP. The average amount of the WTP was not reported.

Heisey (2009) analyses the individual and aggregated WTP for hosting the 2016 Summer Olympic Games for three competition sites (Chicago, San Francisco, Berlin). Chicago has the highest individual $\left(\$ 54.89, € 48.76^{2}\right)$ and aggregated (\$439 million, €390 million) WTP. San Francisco has a smaller individual (\$35.73, €31.74) and aggregated (\$154 million, $€ 137$ million) WTP. The residents of the metropolitan area of Berlin are willing to pay on average $€ 16.35$ only ( $€ 82$ million in the aggregate) for hosting the 2016 Summer Olympic Games. Finally, Coates and Szymanski (2014) examine the WTP of US citizens for hosting the 2024 Summer Olympic Games in the USA. In accordance with the results, US citizens are on average willing to pay $\$ 138.27$ ( $€ 122.84$ ). Projected to the total population above 18 years of age this corresponds to $\$ 33.6$ billion ( $€ 29.9$ billion).

The literature review shows that there is a quite noteworthy WTP for hosting Olympic Games in the own country and city. Interestingly, no study analyses a negative WTP, a WTA, for hosting Olympic Games in the own country or city. To close this research gab, the present study considers this aspect in the empirical analyses.

\section{Theoretical Considerations}

Hosting Olympic Games in the own city or country can be classified as a public good. A public good is characterised by no rivalry in consumption as well as non-excludability in consumption (Mozsár 2003). No rivalry in consumption means that different individuals can consume the good at the same time without affecting the individual utility of consuming this good. Non-excludability in consumption means that it is not possible to prevent non-paying individuals from consuming the good (in this case hosting the Games instead of watching them directly in the stadiums). Hosting Olympic Games in the own country primarily generates benefits for residents of this country without affecting the consumption of other residents of this country (no rivalry) while there is rivalry with other countries that cannot host the same event at the same time. Furthermore, residents cannot be excluded by others from 'consuming' the event and its effects (nonexcludability). In this case, excludability would only be possible with regard to the audience seats. Problems resulting from public goods are mainly provoked by the characteristic of non-excludability. Caused by the non-excludability, each individual has the chance to consume the good without paying for it (free rider problem) such that potential producers are not able to realise sufficient revenues to cover the cost of production. Consequently, private providers do not offer such goods.

${ }^{2}$ US-\$1 equals $€ 0.8884$ by now. Retrieved from: http://www.finanzen.net/waehrungsrechner/us-dol lar_euro. [Accessed 13 June 2020.] 
In addition to the individual WTP and WTA for hosting Olympic Games in Germany, the present study tries to identify determinants that influence the WTP and WTA. For this purpose, we identify three factor groups, namely consumptionrelated factors, intangible factors, and socio-economic factors.

Following Stigler and Becker (1977), individuals are able to generate their own consumption capital and to increase it by repeated consumption of similar goods. Individuals consuming a special good invest in their consumption capital at the same time (Stigler and Becker 1977). Regarding our object of investigation, this means that the interest in sport and specifically in Olympic Games as well as the personal sporting activity lead to a direct benefit of consumption as well as to stocking-up the personal consumption capital. For instance, sports-minded individuals and those who are interested in Olympic Games are more familiar with the effects of hosting sports events in their own country. This knowledge is an essential point to increase one's personal benefit by consuming sports (Schellhaaß and Enderle 1999). Moreover, one's personal sporting activity leads also to a higher WTP. That is because more athletic people can better appreciate the value and benefit of sports events due to their own sporting activity. In addition, they can have a higher WTP because it is more valuable for them to host sports events in their own country in a sport they pursue themselves. For this reason, individuals with a higher sporting activity level should have a higher WTP. Preuß and Werkmann (2011) and Walton et al. (2008) show that a general interest in sport as well as sportive activity are positively associated with the WTP. Therefore, consumption-related determinants that influence the WTP are an interest in sports and the personal sporting activity.

The second group of determinants are intangible factors. From a theoretical point of view, these factors can be attributed to the concept of symbolic capital (Bourdieu 1984, Bourdieu 1989). According to Bourdieu (1984), symbolic capital denotes resources generated by honour, prestige, and recognition. This concept can explain the value of hosting Olympic Games in Germany and the intangible benefits created. Similar to the consumption capital theory, the increased utility of symbolic capital leads to an increased WTP. Regarding the subject of research, hosting Olympic Games in Germany can produce public goods with symbolic character such as pride, prestige or recognition. Pride is determined by the degree of identification with the home country and the national team, in this case the athletes of the German team. It is to be expected that both variables influence the WTP for hosting Olympic Games in Germany in a positive way. Furthermore, prestige is measured by assessing the national importance of a good performance by the national Olympic team, recognition by the personal importance of a good performance. Both variables should increase the WTP because individuals who find it important for themselves and for the national reputation that the German team performs well may be willing to pay more for hosting Olympic Games in the own country. For the present research, it is assumed that intangible factors have a positive influence on the value of hosting Olympic Games in Germany.

The last group of determinants comprises socio-demographic factors like monthly human capital in form of graduation level, net income, age, gender and birthplace. It is assumed that the WTP and WTA differ between individuals with 
different socioeconomic backgrounds. Thus, human capital and income can have a positive impact on the WTP (Atkinson et al. 2008, Coates and Szymanski 2014, Heisey 2009, Preuß and Werkmann 2011, Walton et al. 2008). For example, individuals with higher human capital, measured by a higher education level, may have better skills to assess (positive) effects for tourism or the economy at large resulting from Olympic Games in their own country. Moreover, individuals with a higher income have higher monetary resources at their disposal. The relation between the individual WTP and the age could be strongly connected to the relations of education and income. At a young age, individuals have less income and a lower educational level. As a result, the WTP might be lower for younger individuals. As the individuals mature, the degree of education and the disposable income increase. Thus, individuals should have a higher WTP with increasing age. Typically, pensions are lower compared to previous salaries. Thus, it is conceivable that the WTP of individuals decreases when they retire. Walton et al. (2008) depict a negative effect of age on the WTP while other studies show an insignificant effect of age (Atkinson et al. 2008, Coates and Szymanski 2014, Preuß and Werkmann 2011). With regard to gender, previous studies show that males report a greater WTP than females (Coates and Szymanski 2014, Walton et al. 2008). This interdependency is intuitive because, typically, men are more interested in sport than women. Thus, they might have a greater WTP for hosting Olympic Games in their own city or country to experience this event live and in person. Further, it can be assumed that the birthplace has a positive impact on the WTP for hosting Olympic Games in the own country because it should provide a greater benefit, which results in a higher WTP.

\section{Methodology}

To measure the monetary value of a public good like national defence, environmental protection or in this case hosting Olympic Games, the individual preferences have to be monetarised. The concept of the WTP is an economic concept to express the preferences of the individuals in monetary terms. Likewise, the concept of the WTA (negative WTP) is an economic concept that displays the minimum amount of money that an individual is willing to accept to put up with something negative. Both concepts allow to monetarise public goods and display the utility of the consumers. The amount of the WTP depends on the utility of consuming the public good and increases with it. Based on different preferences, the utility and thus the WTP differs among individuals.

The Contingent Valuation Method (CVM) is an established method to monetarise preferences of consumers regarding certain public goods. By surveys, the CVM identifies the WTP of economic entities for the provision or the withdrawal of a public good. For this purpose, hypothetical scenarios are created where public goods are directly assessable. In these scenarios respondents have to state an amount of money they are willing to pay or accept for the public good considering their individual preferences. Hence, this allows for determining the individual consumer surplus (Coates and Humphreys 2003, Heyne and Süssmuth 
2008, Mitchell and Carson 1989). In the past, the CVM was primarily used in the field of environmental and nature protection (Carson 2011, Davis 1963, Diamond and Hausman 1994, Heyne and Süssmuth 2008, Thayer 1981). Over time, this method has been established in political analyses (Chambers et al. 1998, Groothuis et al. 1998). Johnson and Whitehead (2000) used this method for the first time in the field of sports economics in order to value sport teams economically. For a recent survey of the many uses of the CVM in sports economics in the meantime see Orlowski and Wicker (2019). The present study applies the CVM to determine the WTP for hosting Olympic Games in Germany. The exact scenario created to measure the WTP is presented in the next chapter. We used the statistical programme Stata.

\section{Data}

To measure the WTP for hosting Olympic Games in Germany, the data were collected by using an online questionnaire. The online survey had been available from November 27, 2013 until February 6, 2014. One day later, on February 7, the XXII. Winter Olympic Games in Sotschi started, and ended on February 23. The online-link to access the online questionnaire was published on several social media networks (Facebook, Twitter, and XING) as well as on web pages of the University of Münster. In the following, the structure, as well as the single variables collected, are described.

At the beginning, the questionnaire informed the participants about the topic of the survey. Furthermore, participants were notified that the participation is anonymous, that every data is treated confidentially, and that the information they provide is to be used for scientific purposes only. The questionnaire comprised several questions that can be divided in sport-specific questions and Olympiaspecific questions as well as socio-economic questions. Table 1 provides an overview of the variables collected. 
Table 1. Overview of Variables

\begin{tabular}{|l|l|}
\hline Variables & \multicolumn{1}{|c|}{ Description } \\
\hline WTP_O_GER & WTP for hosting Olympic Games in Germany in $€$ \\
\hline WTA_O_GER & WTA for hosting Olympic Games in Germany in $€$ \\
\hline WTP/A_O_GER & $\begin{array}{l}\text { WTP and WTA (negative WTP) for hosting Olympic Games in } \\
\text { Germany in } €\end{array}$ \\
\hline INT_SPORT & $\begin{array}{l}\text { Interest in sports in general (from } 0=\text { no interest at all to } 4=\text { very } \\
\text { strong) }\end{array}$ \\
\hline SPORT_P & Regular sport participation (at least once per week; $0=$ no; $1=$ yes) \\
\hline ID_GER & Identification with Germany (from $0=$ not at all to $4=$ very strong) \\
\hline ID_TEAM & $\begin{array}{l}\text { Identification with German Olympic team (from } 0=\text { not at all to } 4 \\
=\text { very strong) }\end{array}$ \\
\hline PERS_IMP & $\begin{array}{l}\text { Personal importance that the Olympic team does well (from } 0=\text { not } \\
\text { at all to } 4=\text { very important) }\end{array}$ \\
\hline NAT_IMP & $\begin{array}{l}\text { Importance to country that the Olympic team does well (from } 0= \\
\text { not at all to } 4=\text { very important })\end{array}$ \\
\hline OPTION_O_inG & $\begin{array}{l}\text { Are you in general in favour or against that the Olympic Games are } \\
\text { hosted in Germany }(0=\text { against; } 1=\text { indifferent; } 2=\text { in favour) }\end{array}$ \\
\hline AGE & Age (in years) \\
\hline GENDER & Gender of the respondent $(0=$ female; $1=$ male) \\
\hline GRAD & Educational level (from $0=$ no education to $6=$ university degree) \\
\hline INC 1 & Personal monthly net income up to $€ 1,000$ \\
\hline INC 2 & Personal monthly net income from $€ 1,001$ to $€ 2,000$ \\
\hline INC 3 & Personal monthly net income from $€ 2,001$ to $€ 3,000$ \\
\hline INC 4 & Personal monthly net income from $€ 3,001$ to $€ 4,000$ \\
\hline INC 5 & Personal monthly net income more than $€ 4,000$ \\
\hline BORN_GER & Born in Germany ( $0=$ no; $1=$ yes) \\
\hline
\end{tabular}

Regarding hosting Olympic Games in Germany in general, the participants were asked whether they are in general in favour or against such an event (OPINION_O_inG). In particular, in case that participants were in favour of hosting Olympic Games in Germany they were asked:

"Hypothetically, suppose it would be possible, what is the maximum amount you would be willing to pay for hosting the Olympic Games in Germany?"

If respondents were against Olympic Games in Germany, the constructed scenario was slightly adjusted. The specific question was:

"Hypothetically, suppose it would be possible, how much money (compensation) would it take for you to accept that the Olympic Games are hosted in Germany?"

Moreover, respondents also got questions about their interest in sports in general (INT_SPORT). Furthermore, the participants were asked whether they practice any sport regularly, for example at least once a week (SPORT_P). The questionnaire also contained questions about the respondents' level of identification with Germany (ID_GER) and with the national Olympic team (ID_TEAM). In 
addition, respondents were asked to give information about the importance for them personally (PERS_IMP) and nationally (NAT_IMP), for the reputation of Germany, that the German Olympic team performs well.

At the end of the survey, respondents were confronted with a set of socioeconomic questions about age (AGE), gender (GENDER), graduation level (GRAD), monthly net income (INC), and whether they were born in Germany (BORN_GER).

Before starting with the data evaluation, data and specifically the WTP variables were checked with respect to validity and plausibility. $€ 1,000$ were considered suitable as a plausible limit for both WTP variables. Questionnaires with greater absolute values were not included in the analyses.

\section{Empirical Results}

This chapter contains the descriptive statistics to determine a possible (negative) WTP and the empirical results to identify determinants that influence the WTP for hosting Olympic Games in Germany. Moreover, an extrapolation of the individual WTP leads to the aggregate WTP of the German population.

Table 2 shows the descriptive statistics. Accordingly, 53 percent of the participants are willing to pay for hosting Olympic Games in Germany whereas only 11 percent request a payment to accept their hosting in Germany. Regarding absolute WTP and WTA, participants are on average willing to pay $€ 77.58$ for hosting Olympic Games in Germany (WTP_O_GER). As compensation for hosting Olympic Games in Germany they demand on average $€ 36.71$ (WTA_O_GER).

Regarding further variables, the descriptive statistics show that 78 percent of the participants practice sport regularly. On average, the respondents are moderately to strongly interested in sports in general.

Furthermore, Table 2 shows that the degree of identification with Germany is greater than with the German Olympic team. Nevertheless, both identification features are not very pronounced. In particular, the respondents stated that they neither find it important on the personal level nor on the national level that the German Olympic team performs well at Olympic Games. 
Table 2. Descriptive Statistics

\begin{tabular}{|c|c|c|c|c|c|}
\hline Metric/ordinal variables & Obs. & Mean & S.D. & Min. & Max. \\
\hline WTP_O_GER & 188 & 77.58 & 229.97 & 0 & 1,000 \\
\hline WTA_O_GER & 188 & 36.71 & 168.84 & 0 & 1,000 \\
\hline WTP/A_O_GER & 188 & 40.87 & 295.16 & $-1,000$ & 1,000 \\
\hline INT_SPORT & 351 & 2.57 & 1.04 & 0 & 4 \\
\hline ID_GER & 350 & 2.53 & 0.96 & 0 & 4 \\
\hline ID_TEAM & 396 & 1.54 & 1.12 & 0 & 4 \\
\hline PERS_IMP & 387 & 1.58 & 1.22 & 0 & 4 \\
\hline NAT_IMP & 387 & 1.63 & 1.02 & 0 & 4 \\
\hline AGE & 349 & 26.77 & 9.39 & 16 & 71 \\
\hline INC & 265 & 2.81 & 2.14 & 1 & 9 \\
\hline GRAD & 343 & 5.17 & 1.13 & 1 & 6 \\
\hline Dummy variables & & \multicolumn{4}{|c|}{$\%$ of respondents } \\
\hline WTP_O_GER_D & 188 & \multicolumn{4}{|c|}{52.66} \\
\hline WTA_O_GER_D & 188 & \multicolumn{4}{|c|}{10.64} \\
\hline OPTION_O_inG (against) & 57 & \multicolumn{4}{|c|}{15.04} \\
\hline OPTION_O_inG (indiff.) & 152 & \multicolumn{4}{|c|}{40.11} \\
\hline OPTION_O_inG (in favour) & 170 & \multicolumn{4}{|c|}{44.85} \\
\hline SPORT_P & 366 & \multicolumn{4}{|c|}{77.68} \\
\hline GENDER (1=male) & 349 & \multicolumn{4}{|c|}{52.15} \\
\hline BORN_GER & 349 & \multicolumn{4}{|c|}{95.42} \\
\hline
\end{tabular}

Regarding the opinion variable, 15 percent of the respondents stated that they are against hosting Olympic Games in Germany. Forty percent are indifferent, and 45 percent of the participants are in favour of hosting Olympic Games in Germany.

Concerning socio-economic factors, most respondents have a higher education entrance qualification (Abitur: German equivalent of 'A Levels'), and a personal monthly net income between $€ 501$ and $€ 1,500$. Respondents are on average 26.77 years old with age ranging from 16 to 71 years. According to the official statistics (Statistische Ämter des Bundes und der Länder 2016), only 30 percent of German people are 30 years old or younger. The descriptive statistics also shows that 52 percent of the respondents are males. Thus, 48 percent of the participants are females. In comparison to the gender relation in Germany at large, males are overrepresented in the present dataset. To match the present data with the real gender and age relations in the German population, weights for gender and age are used for further analyses. The weights are calculated based on information by Statistische Ämter des Bundes und der Länder (2016). Finally, descriptive statistics display that 95 percent of the respondents were born in Germany.

In the following, determinants that influence the WTP and WTA for hosting Olympic Games in Germany are presented. The regression analysis is based on a weighted Ordinary-Least-Square (OLS) ${ }^{3}$ regression. The dependent variable is the WTP including the WTA as negative WTP (WTP/A_O_GER).

\footnotetext{
${ }^{3} \mathrm{~A}$ binary-logistic regression leads to similar results. This regression is available upon request.
} 
Table 3. Regression Results of Weighted OLS Regression

\begin{tabular}{|c|c|}
\hline Dependent Variable & WTP/A_O_GER \\
\hline INT_SPORT & $\begin{array}{l}21.71 \\
(0.49)\end{array}$ \\
\hline SPORT_P & $\begin{array}{l}139.91 \\
(0.78)\end{array}$ \\
\hline ID_TEAM & $\begin{array}{l}-89.05^{+} \\
(-1.69) \\
\end{array}$ \\
\hline NAT_IMP & $\begin{array}{c}183.36 \text { *** } \\
(4.37)\end{array}$ \\
\hline AGE & $\begin{array}{c}86.41 * * \\
(2.87)\end{array}$ \\
\hline $\mathrm{AGE}^{2}$ & $\begin{array}{c}-0.96^{* *} \\
(-2.84)\end{array}$ \\
\hline GENDER & $\begin{array}{c}149.71^{+} \\
(1.67)\end{array}$ \\
\hline GRAD & $\begin{array}{l}30.31 \\
(0.98)\end{array}$ \\
\hline INC_1 $(€ 1-€ 1,000)$ & $\begin{array}{c}409.17 * \\
(2.54)\end{array}$ \\
\hline INC_2 $(€ 1,001-€ 2,000)$ & $\begin{array}{c}327.61 * \\
(2.03)\end{array}$ \\
\hline INC_3 $(€ 2,001-€ 3,000)$ & $\begin{array}{c}167.41^{+} \\
(1.63)\end{array}$ \\
\hline INC_4 (€3,001-€4,000) & $\begin{array}{c}6.84 \\
(0.05)\end{array}$ \\
\hline INC_5 (more than 4,001) & REF \\
\hline BORN_GER & $\begin{array}{l}106.19 \\
(0.93)\end{array}$ \\
\hline CONSTANT & $\begin{array}{c}-5,519.66^{* *} \\
(-3.05)\end{array}$ \\
\hline $\mathrm{F}$ & 2.66 \\
\hline Significance & 0.00 \\
\hline $\mathrm{R}^{2}$ & 0.61 \\
\hline
\end{tabular}

Note: $\mathrm{N}=129$, displayed are the unstandardised coefficients, t-values in parentheses. $+\mathrm{p}<0.10$; ${ }_{\mathrm{p}}<$ $0.05 ; *$ * $<0.01 ; * * * \mathrm{p}<0.001$, weighted sample.

Regression results in Table 3 show that the interest in sports in general and practicing sport on a regular basis have no significant impact on the WTP (always including WTA). Interestingly, the identification with the German Olympic team has a significantly negative impact on the WTP. Thus, the WTP decreases by $€ 89.05$ for individuals who identify with the team by one more unit. In contrast to this, individuals who find it nationally important that the German Olympic team performs well have a significantly greater WTP. More concretely, the WTP increases by $€ 183.36$ for individuals who find it more important by one unit that the German Olympic team performs well.

Regarding socio-economic factors, age has a significantly positive impact on the WTP whereas age squared has a significantly negative impact. Therefore, the impact of age on WTP follows an inverted U-shape with a maximum at 45 years. 
Consequently, both younger and older respondents are less willing to pay for hosting Olympic Games in Germany.

As expected, men have a significantly greater WTP than women. Specifically, men are on average willing to pay $€ 149.71$ more than women. The graduation level has no significant impact on the WTP. Thus, there are no significant differences between respondents with no university degree and those who have a graduate degree or who are going for it. Concerning the personal monthly net income, regression results show that the income classes one, two, and three have a significantly positive impact. Respondents with a personal monthly net income between $€ 1$ and $€ 1,000$ are willing to pay $€ 409.17$ more than individuals with a personal monthly net income above $€ 4,001$. In comparison to those participants with a monthly net income of more than $€ 4,001$, the WTP of participants with a monthly net income between $€ 1,001$ and $€ 2,000$ increases by $€ 327$.61. Individuals in the personal monthly net income class of $€ 2,001$ and $€ 3,000$ are willing to pay $€ 167.41$ more than individuals of the reference category. Individuals in the income class between $€ 3,001$ and $€ 4,000$ have no significantly different WTP than individuals who earn more than $€ 4,001$ per month. Lastly, the variable of the birth place has no significant impact on the WTP.

The extrapolation of the weighted data of the individual WTP and WTA for hosting Olympic Games in Germany is shown in Table 4.

Table 4. Extrapolation of the WTP and WTA Differentiated by Gender

\begin{tabular}{|l|c|c|c|}
\hline & Women & Men & $\sum$ \\
\hline WTP & $€ 4.35$ billion & $€ 2.33$ billion & $€ 6.68$ billion \\
\hline WTA & $€ 1.77$ billion & $€ 1.34$ billion & $€ 3.11$ billion \\
\hline WTP-WTA & $€ 2.58$ billion & $€ 0.99$ billion & $€ 3.57$ billion \\
\hline
\end{tabular}

The results show that German women are willing to pay $€ 4.35$ billion in aggregate whereas German men are willing to pay $€ 2.33$ billion. While males have a higher WTP controlling for all other variables in the OLS regression, this is not the case in the extrapolated aggregate, meaning that women have other characteristics that boost their WTP. In sum, the German population is willing to pay $€ 6.68$ billion. An extrapolation of the WTA for hosting Olympic Games in Germany shows that women demand $€ 1.77$ billion while men demand $€ 1.34$ billion (in sum €3.11 billion) to accept that the Olympic Games are hosted in Germany. Subtracting WTA from WTP indicates that Germans are willing to pay $€ 3.57$ billion for hosting Olympic Games in Germany, much smaller than the estimated €7.4 billion cost of hosting the 2024 Summer Olympic Games in Hamburg.

\section{Conclusion}

This study tried to answer the question how many German individuals are willing to pay or willing to accept to host the Olympic Games in Germany. Considering WTA in this context is new to the literature. The approach allows for 
determining both hypothetical payments to have the Olympic Games hosted in Germany and hypothetical compensations needed to accept that the Olympic Games are hosted in Germany. The used data set, generated with an online questionnaire, shows that 53 percent of the respondents have a positive WTP whereas 11 percent of the participants request compensation to accept that Olympic Games are hosted in Germany. On average, participants stated that they are willing to pay $€ 77.58$ for hosting Olympic Games in Germany. In contrast to this, participants who are against Olympic Games in their own country stated that they demand on average $€ 36.71$ as a compensation for hosting Olympic Games in Germany. The extrapolation of the individual WTP and WTA leads to an aggregated WTP of $€ 6.68$ billion, and to an aggregated WTA of $€ 3.11$ billion. Put together, this leads to a positive net balance of $€ 3.57$ billion. This figure can be interpreted as the maximum amount Germans are willing to pay for Olympic Games in their country (with caution given the limits of the used data). Certainly, the whole costs for hosting Olympic Games should not be imposed on the residents of the hosting city or county alone. This would cause residents to vote against hosting Olympic Games in the own city or county as has been the case in cities like Hamburg (Wicker and Coates 2018) or Munich.

Regarding the determinants that influence the WTP, regression results show that in particular the socio-demographic factors influence the WTP in a significant way. As expected, the gender variable has a significantly positive impact. This means that males stated a greater WTP for hosting Olympic Games in Germany. This is hardly surprising as men are typically more interested in sport than women. The keener interest translates into greater WTP for hosting Olympic Games in the own country that also makes it easier to see this event live and in person. Similar results can be found in Coates and Szymanski (2014), Walton et al. (2008), and Wicker et al. (2017). Regarding the age, WTP follows an inverted U-shape with a maximum at 45 years. Thus, both younger and older people are less willing to pay for hosting Olympic Games in Germany. One possible explanation might be that younger people may not be able to assess the value of hosting Olympic Games for lack of experience. This means that they cannot evaluate whether hosting Olympic Games cause positive or negative effects for the home country. Due to this fact, they are less inclined to pay for hosting Olympic Games. As one result of bad publicity regarding hosting mega sport events - for example reports on Sotschi before and after the Winter Olympic Games - the WTP for hosting Olympic Games in the own country might decrease. Middle-aged people appear to be rather optimistic with respect to the opportunities resulting from hosting Olympic Games in their own country, while older people are less interested (Walton et al. 2008). Considering the income variables, the regression results show that the three lower income classes have a significantly positive impact on the WTP (contrary to Atkinson et al. 2008, Coates and Szymanski 2014, Heisey 2009, Preuß \& Werkmann 2011, Walton et al. 2008). This means that individuals with a personal monthly net income between $€ 1$ and $€ 3,000$ have a greater WTP than individuals with a personal monthly net income of more than $€ 4,000$. Regarding the absolute value, respondents with a personal monthly net income between $€ 1$ and $€ 1,000$ have the greatest WTP. One conclusion may be that with an increase of the 
personal monthly net income other interests predominate the interest in hosting Olympic Games in the own country. The graduation level and the birthplace both have a positive sign regarding the WTP. However, they are not statistically significant and thus need no further explanation.

In need of explanation is the significantly negative impact of the identification with the German Olympic team. The negative effect of the identification variable suggests that the identification with the German Olympic team is a substitute for the WTP. This suggests that as individuals already identify with the German Olympic team they do not feel obliged to pay for having the team compete in Olympic Games in the own country. The level of national importance influences the WTP in a significantly positive way. This means that individuals who find it on a national level important that the German Olympic team performs well have a greater WTP for hosting Olympic Games in Germany. In other words, the WTP increases with national pride. Therefore, individuals with greater national pride have keener interest in hosting Olympic Games in their own country to present the country and its strengths in sports to the world.

In terms of methodology, it would be interesting to examine in more detail which respondents may have misunderstood the WTP as a kind of bribery instead of as an equivalent for the subjective utility. Therefore, it is not clear whether the CVM overestimates or underestimates the real value of sport events. The overestimation arises from statements of high amounts because they are free of real costs. The underestimation arises because some individuals state no WTP even though they value this event. In any case, to complement the question concerning the WTP with the question of a potential WTA is very important for determining the real value because the positive WTP alone is clearly an overestimation. Furthermore, it would be interesting to study differences between the WTP for hosting Olympic Games in the own country and in the own city. The outcomes of the referenda in Hamburg and Munich are relevant for future votes for hosting Olympic Games in other cities. Finally, it could be worthwhile to replicate this kind of study for other countries (and with representative samples). The country with the highest WTP (less WTA) would be a good candidate for hosting the Olympic Games.

\section{References}

Atkinson G, Mourato S, Szymanski S, Ozdemiroglu E (2008) Are we willing to pay enough to 'back the bird'? Valuing the intangible impacts of London's bid to host the 2012 Summer Olympic Games. Urban Studies 45(2): 419-444.

Bourdieu P (1984) Distinction: a social critique of judgment of taste. Cambridge, MA: Harvard University Press.

Bourdieu P (1989) Social space and symbolic power. Sociological Theory 7(1): 14-25.

Carson RT (2011) Contingent valuation: a comprehensive history and bibliography. Cheltenham: Edward Elgar Publishing Limited.

Chambers CM, Chambers PE, Whitehead JC (1998) Contingent valuation of quasi-public goods: a validity and reliability assessment. Public Finance Review 26(2): 137-154. 
Coates D, Humphreys BR (2003) Professional sport facilities: franchise and urban economic development. Public Finance and Management 3(3): 335-357.

Coates D, Szymanski S (2014) Willingness to pay to host the summer Olympic Games. Working Paper. USA: University of Maryland Baltimore County.

Davis RK (1963) The value of outdoor recreation: an economic study of the Maine Woods. Doctoral Dissertation. Cambridge, USA: Harvard University.

Diamond PA, Hausman JA (1994) Contingent valuation: is some number better than no number? Journal of Economic Perspective 8(4): 45-64.

Groothuis PA, Van Houtven G, Whitehead JC (1998) Using contingent valuation to measure the compensation required to gain community acceptance of a LULU: the case of a hazardous waste disposal facility. Public Finance Review 26(2): 231-249.

Heisey K (2009) Estimating the intangible benefits of hosting the 2016 Olympic and Paralympic Games for potential bid cities: Berlin, Chicago, and San Francisco. Doctoral Dissertation. Cologne, Germany: German Sport University.

Heyne M, Süssmuth B (2008) Wie viel ist den Deutschen die Ausrichtung der FIFA WM 2006 wert und warum? [The willigness-to-pay to host the 2006 FIFA World Cup in Germany.] In M Klein, M Kurscheidt (eds), Neue Perspektiven ökonomischer Sportforschung. Schorndorf: Hofmann.

Johnson BK, Whitehead JC (2000) Value of public goods from sports stadiums: the CVM approach. Contemporary Economic Policy 18(1): 48-58.

Mitchell RC, Carson RT (1989) Using surveys to value public goods: the contingent valuation method. Washington: Resources for the Future.

Mozsár F (2003) On the notion of public goods. In I Lengyel (ed), Knowledge transfer, small and medium-sized enterprises, and regional development in Hungary. Szeged: JATE Press.

Müller M (2014) After Sochi 2014: costs and impacts of Russia's Olympic Games. Eurasian Geography and Economics 55(6): 628-655.

Orlowski J, Wicker P (2019) Monetary valuation of non-market goods and services: a review of conceptual approaches and empirical applications in sports. European Sport Management Quarterly 19(4): 456-480.

Preuß H, Werkmann K (2011) Erlebniswert Olympische Winterspiele in München 2018 [Experiential value of the Winter Olympic Games in Munich 2018.] Sport und Gesellschaft 8(2): 97-123.

Schellhaaß HM, Enderle G (1999) Wirtschaftliche Organisation von Sportligen in der Bundesrepublik Deutschland. [Economic organisation of sports leagues in the Federal Republic of Germany]. Cologne: Buch und Strauß.

Statistische Ämter des Bundes und der Länder (2016). Bevölkerungsstand: Bevölkerung nach Geschlecht und Altersgruppen: Stichtag 31.12.2013. [Population level: human population differentiated by age and gender: record date December 31, 2013]. Retrieved from: https://bit.ly/3jirrC8. [Accessed 24 March 2016.]

Stigler GJ, Becker GS (1977) De gustibus non est disputandum. [There is no disputing about tastes.] American Economic Review 67(2): 76-90.

Thayer MA (1981) Contingent valuation techniques for assessing environmental impacts: further evidence. Journal of Environmental Economics and Management 8(1): 27 44.

Walton H, Longo A, Dawson P (2008) A contingent valuation of the 2012 London Olympic Games. Journal of Sports Economics 9(3): 304-317.

Wicker P, Whitehead JC, Mason DS, Johnson BK (2017) Public support for hosting the Olympic Summer Games in Germany: the CVM approach. Urban Studies 54(15): 3597-3614. 
Wicker P, Coates D (2018) Flame goes out: determinants of individual support at the 2024 Hamburg Games referendum. Contemporary Economic Policy 36(2): 302-317. 
